\section{SPOTLIGHT ON}

EXTINCTION

\section{Parasite extinctions could have dramatic effects on ecosystems}

Although parasites can harm and even kill their hosts, many parasitic species are threatened, and their plight has been largely overlooked because of their negative image. However, such blanket prejudice against a group of organisms could be dangerous. Less than a century ago, apex predators were widely exterminated because their removal was thought to be beneficial, which overlooks their vital role in ecosystems. Parasites are equally fundamental: they far outnumber free-living organisms, and at least $70 \%$ of food web interactions are between parasites and their hosts. Parasites are threatened by loss of host species and changing environmental conditions. Up to $30 \%$ of parasitic worms are facing extinction within 50 years, and even more of the external parasites such as lice and ticks. The loss of parasites could even be bad for their hosts, as their absence could interfere with the proper functioning of the host's immune system. Source: New Scientist (2019) newscientist. com/article/mg24432540-500-parasitesare-going-extinct-in-droves-and-weshould-be-very-worried

\section{Reasons for plant extinctions vary across space and time}

A team of researchers studied cases of plant extinction in global biodiversity hot- and coldspots, demonstrating that the extinction rate of plants is currently 350 times higher than the average during the period studied, 300 years. Extinction rates are apparently higher in biodiversity hotspots than in coldspots, but extinction rates have overall declined in recent years. The most threatened species are perennial herbs in temperate regions, and the main reasons for plant extinctions are agricultural expansion and urbanization. In hotspot regions, another threat comes from invasive non-native plants and animals that often cause harm to local flora and fauna. In biodiversity coldspots, changes in the hydrological regime of habitats may also cause plant extinctions.

Sources: Current Biology (2019) doi.org/10. 1016/j.cub.2019.07.063 \& SciTechDaily

(2019) scitechdaily.com/study-finds-reasons-for-plant-extinction-vary-across-theworld-and-over-time

\section{USA's threatened species struggle to adapt to climate crisis}

The climate crisis is poised to deliver a severe blow to the most threatened animals of the USA. A study found that almost every species considered at risk of extinction is vulnerable to global heating. Of the 459 animal species listed as endangered by the US government, all but one (99.8\%) have characteristics that will make it difficult for them to adapt to rising temperatures. Amphibians, molluscs and arthropods are sensitive to the greatest number of climate-related threats, such as changes in water quality, shifting seasons and harmful invasive species. Mammals such as the north Atlantic right whale and Florida panther also face increased hardships. Despite these findings, federal agencies consider only $64 \%$ of endangered species to be threatened by the climate crisis, and only $18 \%$ of listed species have protection plans in place.

Sources: Nature Climate Change (2019)

doi.org/10.1038/s41558-019-0620-8 \&

The Guardian (2019) theguardian.com/ environment/2019/nov/19/endangeredspecies-us-climate-crisis

\section{Presumed-extinct miniature deer reappears in the wild}

A species of miniature deer, approximately the size of a cat and thought to have been hunted to extinction in the 1990s, has been rediscovered. The silver-backed chevrotain Tragulus versicolor is so small it could be held in one hand. Records of the species' existence go back to the stone age, when it was depicted in cave art being chased by hunters. It has only been recorded once since 1907, with the last sighting in 1990 in the Annamite Mountains in Viet Nam, and was believed to have become extinct soon after. The species was prized by local hunters, who sought to satisfy the growing demand for bushmeat and used small snares to catch the rare animals. The team conducted interviews with villagers to identify possible chevrotain sightings and used this local knowledge to place over 30 motion-activated camera traps in the forest. In 6 months they recorded almost 300 independent detections of the animal. However, the number of distinct individuals is still unknown. Sources: Nature Ecology \& Evolution doi.org/10.1038/s41559-019-1027-7 \& The Independent (2019) independent.co.uk/ news/science/deer-extinct-silver-backedchevrotain-endangered-species-vietnama9198696.html

\section{Malaysia's last Sumatran rhinoceros dies}

The last Sumatran rhinoceros Dicerorhinus sumatrensis in Malaysia died in November 2019, leaving the smallest species of rhinoceros, which once roamed across Asia, surviving in small numbers mostly on the Indonesian island of Sumatra and on the Indonesian side of Borneo. The 25-year-old female named Iman, who had been cared for in a wildlife reserve since her capture in 2014, died of cancer in the state of Sabah on the island of Borneo. The Sumatran rhinoceros was declared Extinct in the Wild in Malaysia in 2015. The country's last male died in May 2019. The species has now almost disappeared from the wild, and conservationists estimate that only $30-80$ individuals survive. Their isolation, caused by habitat loss and poaching, means they rarely breed and may become extinct in a matter of decades. Since 2011, Malaysia has tried to breed the species in captivity through in-vitro fertilization, but without success.

Source: Reuters (2019) uk.reuters.com/ article/us-malaysia-wildlife-rhino/ malaysias-last-sumatran-rhinocerosdies-idUKKBN1XXoHG

\section{Carolina parakeet extinction was driven by anthropogenic causes} Researchers have unveiled the genome of the Carolina parakeet Conuropsis carolinensis, a North American bird declared Extinct at the beginning of the 2oth century. Flying in flocks of hundreds of individuals, it was extensively hunted during the late $18 \mathrm{oos}$, in part for obtaining its feathers to decorate hats. However, the cause of its extinction remained contentious. Researchers sampled tissue of a specimen preserved in a private collection in Spain. To map the complete genome of the extinct bird, they had to first sequence the genome of a close living relative, the sun parakeet Aratinga solstitialis from South America. They also explored the genome for signs of inbreeding and population decline that are sometimes found in threatened species but did not find them, which suggests that its rapid extinction was mainly human-mediated. The methodology developed to reconstruct the extinction history from the bird's genome could be used in the future to foresee other possible anthropogenic extinctions. Sources: Current Biology (2019) doi.org/10. 1016/j.cub.2019.10.066 \& Phys.org (2019) phys.org/news/2019-12-carolina-parakeetextinction-driven-human.html 


\section{INTERNATIONAL}

\section{Expedition of 100 women from STEMM fields to Antarctica}

One hundred women from the fields of science, technology, engineering, mathematics and medicine (STEMM) spent 3 weeks in Antarctica in late 2019, studying the effects of climate change and the global-scale response that is required. The expedition, part of a year-long programme called Homeward Bound, is a global leadership initiative supporting women in STEMM. Women's empowerment and improved gender equality can help combat climate change, suggesting that the future stability of the planet could depend in part on bringing more women into decision-making roles. Alumni of the Homeward Bound programme return to their respective fields as part of a global network of women with an enhanced understanding of the skills and leadership required to advocate for, influence, and act on the climate crisis. Three such cohorts have graduated from the Homeward Bound programme since its first expedition in 2015.

Source: Your Story (2019) yourstory.com/ herstory/2019/11/hundred-women-stemmantartica-sustainable-future

\section{Scientists advocate mega-conservation approach}

Although saving rare and charismatic species such as pandas and snow leopards is important in its own right, the most efficient conservation solutions may come from the protection of widespread ecosystems. Researchers behind the first compendium of world aspen communities (genus Populus) are advancing the concept of socalled mega-conservation, whereby protecting and restoring widespread, common species could offer strategic advantages over a more traditional, single-species approach. Prioritizing the preservation of keystone ecosystems such as aspen forests, which support numerous species throughout much of the northern hemisphere, enables continentalscale conservation practices, with benefits for global biodiversity. A comprehensive review of aspen science, threats, and restoration practices found healthy aspen forests enhance biodiversity, facilitate rapid recolonization of disturbed habitats, and provide adaptability in changing environments. The researchers highlighted other potential widespread keystone communities such as sage steppes in Europe and North America, taiga forests in Eurasia, and Eucalypt forests in Australia.

Source: Phys.org (2019) phys.org/news/ 2019-11-biodiversity-scientists-mega-conservation.html

\section{IUCN programme to halt species} loss

In October 2019, leaders of the IUCN Species Survival Commission gathered in Abu Dhabi, United Arab Emirates, and called for governments to take emergency measures to save those species at the highest risk of extinction. The call is in part a result of the fact that it is now recognized that conservation targets set in 2010 will not be met, despite substantial efforts from conservationists worldwide. Issues highlighted by the Commission include poor agricultural practices and wildlife crime. A global programme of Work on Species Conservation will be launched in June 2020, and the IUCN calls on parties to the Convention on Biological Diversity and other biodiversity-related conventions to implement the programme with urgency. The aim is that by 2030 human-driven extinctions will have halted as the private sector and governments will have accepted their role in tackling this issue and will have taken measures to rectify it. Then by 2050 it is hoped that there will be recovery of the most threatened species globally. Source: IUCN (2019) iucn.org/news/ species-survival-commission/201910/iucncalls-halt-species-decline-2030

\section{Oceans losing oxygen at a dangerous, unprecedented rate}

The world's oceans are struggling to breathe, rapidly running out of oxygen at an unprecedented rate. Climate change is dangerously exacerbating the issue. The IUCN released the largest report of its kind-combining the efforts of 67 scientists from 17 countries-at the global climate summit in Madrid, Spain, in December 2019. It found that the oxygen level in the ocean has declined by about $2 \%$ since the 1950 , and the volume of water completely depleted of oxygen has quadrupled since the 1960 s. Sixty years ago, only 45 ocean sites suffered from low oxygen levels. That number skyrocketed to 700 in 2011. According to the study, c. $50 \%$ of oxygen loss in the upper part of the ocean is a result of temperature increase. Scientists predict that a combination of climate change and increased nutrient discharge will cause a $3-4 \%$ decrease in ocean oxygen levels on average by 2100 if business continues as usual. Researchers named two major causes of deoxygenation: ocean warming from burning fossil fuels and eutrophication through excessive growth of algae.

Source: CBS News (2019) cbsnews.com/ news/worlds-oceans-are-losing-oxygen-ata-dangerous-unprecedented-rate-astemperatures-rise
Pacific seals and sea otters at risk as disease spreads from Atlantic

Samples taken from seals, sea lions and sea otters in Alaska during 2001-2016 reveal that a potentially deadly disease has spread from the North Atlantic Ocean to the northern Pacific, because of melting Arctic sea ice. Phocine distemper virus is spread through contact between infected individuals, and it can kill animals within 10 days of contracting the disease. It was first recognized in 1988 following a devastating epidemic among harbour and grey seals in north-western Europe, with a similar outbreak killing c. 30,000 seals in 2002. Scientists think Arctic sea ice prevented the virus' entry into the Pacific, but with climate change causing extensive melting, pathways are opening up for wildlife and pathogens to move between the two oceans. Scientists have confirmed that the Pacific marine mammals were infected with the Atlantic strain of the virus, with incidences peaking during periods of low sea ice extent.

Source: The Guardian (2019) theguardian. com/environment/2019/nov/17/pacific seals-ate-risk-arctic-ice-melt-diseasespread-atlantic-otters

\section{New insights on whale shark behaviour and conservation}

An international team of researchers has performed an extensive study of whale shark Rhincodon typus movement and residency using a combination of three scientific techniques: visual census, acoustic monitoring and satellite telemetry. The 6year study tracked the animals' long-term movement patterns near the Shib Habil reef, a known whale shark hotspot in the Red Sea. The team monitored a total of 84 individual sharks, and their findings shed light on whale shark behaviours, which could help to inform conservation efforts. The researchers found the aggregation to be highly seasonal, with sharks being most abundant in April and May. Many of the sharks returned to the hotspot locality regularly year after year. The study also showed roughly equal numbers of male and female sharks using the site, something that could be unique to Shib Habil. These characteristics indicate that this site could be a nursery and may serve an important function for the wider Indian Ocean population of this rare and threatened species.

Sources: PLOS ONE (2019) doi.org/10.1371/ journal.pone.0222285 \& SciTech Daily (2019) scitechdaily.com/six-year-whaleshark-study-offers-new-behavior-andconservation-insights-video 


\section{EUROPE}

\section{EU not on track to achieve Sustainable Development Goals}

The 2019 Europe Sustainable Developmen Report, which was published in November last year, revealed that European countries lead globally on the Sustainable Development Goals set by the United Nations. All the countries closest to achieving the Goals are in Europe: Denmark, Sweden, Finland, France, Austria, Germany, Norway, Netherlands, Czech Republic, Slovenia and Estonia. Yet none are on track to achieve the Goals by 2030. The report identified key priorities for the EU to achieve the Goals and to implement the Paris Climate Agreement. Progress is needed towards climate change, sustainable consumption and production, conservation of biodiversity, and sustainable agriculture and food systems. Education and innovation capacities must be improved to raise living standards in poorer member states. Countries in Central and Eastern Europe face greater poverty rates and material deprivation, and gaps across population groups in access to care, quality education, and infrastructure. Source: Emerging Europe (2019) emergingeurope.com/news/the-eu-is-not-on-trackto-achieve-the-sustainable-developmentgoals

\section{Climate change causes drying of European peatlands. .}

Peatlands are found in almost every country, from blanket bogs in the UK to swamp forests in South-east Asia. They are a natural carbon sink; in Europe they lock up c. five times more carbon than forests. But according to a new study, the continent's peatlands are becoming dry and fragile and could start releasing rather than absorbing carbon. Researchers examined 31 peatlands across Europe to assess changes during the last 2,000 years. Most peatlands had become drier during $1800-$ 2000 than they had been for the last 600 years, with $40 \%$ being drier than they had been for 1,000 years, and $24 \%$ drier than they had been for 2,00o years. This change is concurrent with a dryer and warmer climate and direct human impacts on peatlands. The results suggest that the wetness of many European peatlands may now be moving away from natural baselines. Effective management and restoration of peatlands is needed urgently to restore and safeguard these boggy landscapes. Sources: Nature GeoScience (2019) doi.org/ 10.1038/s41561-019-0462-z \& BBC (2019) bbc.co.uk/news/science-environment50124001
... and modified masterpieces illustrate climate change

To coincide with the 2019 UN Climate Change Conference COP25, held in Madrid in December 2019, the Spanish capital's Museo del Prado teamed up with conservation group WWF for an awareness raising campaign, releasing a selection of four modified masterpieces that showcase the potential consequences of climate change. The initiative points to rising global temperatures and calls for governments to take action to ensure that the increase does not exceed $1.5{ }^{\circ} \mathrm{C}$. Four paintings from the Prado's collection were selected for the campaign: El Paso de la Laguna Estigia by Joachim Patinir, El Quitasol by Francisco de Goya, Niños en la Playa by Joaquín Sorolla, and Felipe IV a Caballo by Velázquez. The modified works address rising sea levels, the threat of species extinctions, the impact of extreme droughts, and social discord surrounding climate refugees. The images were presented on billboards throughout Madrid's city centre, and as part of WWF's digital engagement campaign.

Source: Artnet News (2019) news.artnet.com/ art-world/museo-del-prado-wwf-paintingmasterpieces-climate-change-1721970

EU ruling on wolf hunting in Finland. In October 2019, the European Court of Justice issued a preliminary ruling on wolf hunting in Finland, setting a number of conditions on the hunting of wolves for population management purposes. It stipulated, for example, that the granting of permits to hunt wolves must be based on rigorous and unambiguous scientific data. Jari Leppä, Finland's Minister of Agriculture and Forestry, called the decision a setback for the country, stating that he believes hunting is necessary in the effort to manage the wolf population in the country as it would ensure the animals continue to fear humans. The Finnish Wildlife Agency had argued that hunting for population management purposes can reduce poaching. However, the Court ruled that there is no scientific evidence that the legal hunting of a protected species reduces poaching to an extent that it would have an overall positive effect on its conservation status. The Finnish Association for Nature Conservation welcomed the preliminary ruling, stating that it should lead to stricter conditions for derogation hunting permits. Source: Helsinki Times (2019) helsinkitimes. fi/finland/finland-news/domestic/16954-euruling-on-wolf-hunting-a-setback-forfinland-views-leppae.html
... reintroduced Eurasian curlews shot in France...

In Poland, where the population of the Eurasian curlew Numenius arquata has decreased by $50 \%$ during the last 10 years, scientists are investing in a reintroduction scheme to bolster the population of c. 300 pairs. However, it was reported that a bird reintroduced and fitted with a satellite tracker in Poland suddenly stopped moving in Normandy in the summer of 2019, in a known hunting area. During the 3 years prior, at least five such cases have been documented, probably representing only a fraction of the true numbers. In France, a moratorium suspending the hunting of the threatened wader had expired at the end of July 2019, which temporarily allowed the legal hunting of curlews before the government fixed the hunting quota at zero almost a month later, to meet the country's obligations under the EU Birds Directive. France is the last remaining EU country to allow any shooting of the Eurasian curlew. Of the 64 bird species currently hunted in France (the highest number in Europe), 20 are listed on the IUCN European Red List of Threatened Species.

Source: BirdGuides (2019) birdguides.com/ news/reintroduced-eurasian-curlewsshot-in-france

\section{.. and hunters of rare Swiss ibex sti Alps wildlife row}

Centuries of intensive hunting reduced Alpine ibex Capra ibex numbers to just a few hundred, found in one area of northern Italy. But in the late 2oth century the numbers recovered, particularly in Switzerland where the ibex was reintroduced from Italy. Today $>40,000$ ibexes are estimated to be roaming in the Alps, and Switzerland hosts the largest population with c. 16,000. Controversially, trophy hunters can now shoot the species again in one Swiss region. The Swiss ibexes live mainly in the high mountains of two southern regions (cantons), Valais and Graubünden. Graubünden only allows locals to hunt the species, but Valais now includes foreigners in its quota of ibex hunting licences. Approximately 450 ibexes are shot annually in Valais, and 500 in Graubünden, which harbours $40 \%$ of Switzerland's ibex population. But in neighbouring Italy and France ibex hunting is banned. WWF Switzerland has criticized trophy hunting in Valais, questioning its legality. Conservationists opposed to a revised Swiss Hunting Act have been collecting signatures in a bid to hold a national referendum on the issue.

Source: $B B C$ (2019) bbc.co.uk/news/worldeurope-50303932 


\section{AFRICA}

\section{One-third of tropical African flora potentially threatened}

Industrial-scale activities such as timber exploitation, large plantations, mining and agriculture present major threats to biodiversity in the tropics. Although preserving tropical biodiversity is urgent, the extinction risk of most plant species in these regions has not been assessed, which makes it difficult to identify conservation priorities. To fill this gap, a team of researchers used a novel approach aligned with IUCN Red List criteria and carried out a computer analysis of the status of $>22,000$ vascular plant species in tropical Africa. They found 33\% of the species are potentially threatened with extinction, and another third are probably rare and may become threatened in the future. In four regions $>40 \%$ of species are potentially threatened: Ethiopia, West Africa, central Tanzania, and southern Democratic Republic of the Congo. The study is a first step toward data-driven conservation assessments applicable at continental scales.

Source: Science Advances (2019) doi.org/10. 1126/sciadv.aax9444

\section{Debate rages over intensive oil palm farming in Gabon}

Nearly $88 \%$ of Gabon is covered in forests, but oil palm plantations could threaten this resource. In 2015 the Gabonese authorities formed a public-private partnership with oil palm firm Olam Palm Gabon for the development of a 58,500 ha tract. Local communities had initially welcomed this, hoping to improve their economic situation, but are now accusing the company of land grabbing. The communities want to protect their traditional rights to use the forest for farming and harvesting, to ensure their food sovereignty. They also criticize the company for creating insecure jobs and reportedly paying low salaries to workers. Environmental NGOs have pointed out risks for nature and communities in the further expansion of oil palm plantations. But supporters of the project praise the company's respect for the environment, basic community social commitments and creation of sustainable jobs. The NGO Croissance Saine Environnement stated the development was $100 \%$ compliant with zero-deforestation principles and all development had taken place with the communities' consent.

Source: Mongabay (2019) news.mongabay. com/2019/11/debate-rages-over-intensive-

oil-palm-farming-in-gabon

\section{African Parks: privatizing elephant conservation in Chad. .}

Fifty years ago, there were c. 300,000 elephants in Chad, but from the mid 1980 s that number declined catastrophically as a result of poaching. Zakouma National Park, in south-eastern Chad, became a refuge for the largest remnant group of c. 4,000 animals. However, $>90 \%$ of Zakouma's elephant population was killed during 2000-2010, mostly by Sudanese paramilitary poachers. Then in 2010, at the invitation of the Chadian government, the private organization African Parks took over management of Zakouma, and the poaching stopped. Founded in 2000 by a small group of conservationists, the non-profit organization contracts with governments to restore and run national parks, exercising full control on the ground. African Parks now manages at least 15 parks in nine countries, bringing outside funding, efficient business practices and rigorous law enforcement to some of Africa's most troubled wild landscapes. With the help of the dedicated rangers, the elephants of Zakouma are recovering and reproducing. Their population now includes c. 150 calves, a sign of health and hope.

Source: National Geographic (2019) national geographic.com.au/animals/to-savewildlife-african-governments-turnto-private-management.aspx

\section{.. and rangers honoured at 2019 African Ranger Awards}

In November 2019 the Paradise International Foundation and the Alibaba Foundation hosted the second annual edition of the African Ranger Awards to honour the 50 finalists of the year. Selected from 17 countries across the continent, the finalists were recognized for their exemplary leadership and commitment to these vital places, where their actions deliver security and create safe places so that ecosystems can function, and people and wildlife can benefit from them. The interconnection of the state of Africa's wildlife and the prosperity of its people were highlighted during the event's keynote speech. Without natural resources, the pressures of poverty will continue to fuel more conflicts, insecurity and instability. Seven awardees belonged to African Parks, which has the largest ranger team of any NGO in Africa, with over 1,000 rangers in 10 countries. Globally over the past decade, almost 1,00o rangers have lost their lives countering the myriad threats on the frontline of conservation. Source: Zambia Reports (2019) zambiareports.com/2019/11/24/seven-africanparks-rangers-honoured-2019-africanranger-awards
Malawi receives 17 black rhinoceroses from South Africa

Seventeen black rhinoceroses Diceros bicornis have been released into Malawi's Liwonde National Park as part of conservation efforts aimed at keeping the local population of the Critically Endangered species, which is threatened by poaching for its horn, healthy and safe. Conservationists hope the translocation from South Africa will ensure wild black rhinoceroses remain genetically diverse to better fight off disease. Two rhinoceroses had been translocated from Kruger National Park in 1992, and this new transfer was organized by wildlife departments in the two countries and WWF South Africa. The rhinoceroses were captured in KwaZulu-Natal, South Africa, and quarantined for six weeks at Imfolozi Game Reserve before they were flown from King Shaka airport in Durban to Lilongwe in Malawi. The translocation was praised as a great boost to the species and a sign of South Africa's confidence in Malawi's concerted efforts to improve wildlife security.

Source: Reuters (2019) uk.reuters.com/ article/uk-malawi-rhino/malawi-receives17-black-rhinos-from-south-africaidUKKBN1XN1YE

\section{Mass wildlife translocation in Zimbabwe after severe drought}

Towards the end of last year, one of the region's worst droughts in decades dried up grazing land and water sources in Zimbabwe. More than 200 elephants and many other animals perished in national parks during September-November 2019 because of a lack of food and water. The wildlife agency issued permits to translocate 600 elephants from Save Valley Conservancy in southern Zimbabwe, one of the largest private game reserves in Africa, to three other national parks. Numerous antelopes, buffalos, giraffes, lions and wild dogs were also planned to be moved, making this the largest translocation of wildlife in the country's history. Zimbabwe is home to one of the largest elephant populations on the continent, with an estimated 85,000. But the survival of wildlife is threatened as persistent drought strangles swaths of southern Africa, devastating crops, grasslands and water holes. The region's people are also largely dependent on rain-fed, smallholder agriculture and face critical food insecurity as a result of the extreme weather. Temperatures in southern Africa are rising at twice the global average.

Source: ABC News (2019) abcnews.go.com/ International/zimbabwe-plans-mass-wildlifemigration-hundreds-elephants-die/story 


\section{AMERICAS}

\section{Deforestation in Brazil expected to worsen in 2020}

Development, most of it illegal, destroyed more than $9,700 \mathrm{~km}^{2}$ of Brazilian Amazon rainforest during July 2018-July 2019, according to a government estimate released in November 2019; an increase of $30 \%$ from the previous year and the highest rate of deforestation since 2007-2008. The number is based on analysis of highresolution Landsat satellite images by the Program for Monitoring Deforestation of the Amazon by Satellite, run by Brazil's National Institute for Space Research. The estimate confirms indications of increased forest loss reported earlier in 2019 by the Real-Time Deforestation Detection System, which uses lower resolution satellite images for monitoring of illegal activities. Many scientists and environmentalists blame the deforestation spike on President Jair Bolsonaro's aggressive policies to support mining and ranching, and to dismantle the country's environmental institutions and effectively halt fines for illegal land clearing. However, Minister of the Environment Ricardo Salles stated that increased deforestation began in 2012, before Bolsonaro was elected.

Source: Science Magazine (2019) sciencemag.org/news/2019/11/brazil-s-deforestation-exploding-and-2020-will-be-worse

\section{Scarlet ibis back in Florianópolis after a 200-year absence}

A flock of c. 1,00o scarlet ibis Eudocimus ruber arrived in the Brazilian city of Florianópolis in November 2019, some 200 years since they were last seen there. The capital of Santa Catarina state, the city is located on Santa Catarina island just off the country's southern coast. Researchers were pleased to document the presence of the bird, known in Brazil as the guará, after its long absence. They suspect the cause of the species' return lies in recent efforts to restore the island's mangroves. It is thought that mangrove degradation was the main factor in driving away the island's guarás. Although the species is categorized as Least Concern on the IUCN Red List, biologists and birdwatchers are encouraged by its reappearance in Florianópolis and see it as a possible indicator of the mangroves' improved state.

Source: Folha de S. Paulo (2019) folha.uol. com.br/internacional/en/scienceandhealth/ 2019/11/absent-for-200-years-flamingolike-birds-have-returned-to-color-theflorianopolis-sky.shtml

\section{Extractive industries in Ecuador increasing pressure on jaguars}

The greatest threat faced by the jaguar Panthera onca in Ecuador is habitat loss, with vast areas of the country's rainforest lost to logging and agricultural expansion. Along the coastline, $>70 \%$ of the original forest cover has disappeared, and the IUCN has declared the coastal jaguar population Critically Endangered. Besides forest clearance for products such as cacao, coffee, palm oil and bananas, plans for the construction of new roads to allow access for pit mining and oil extraction pose increasing problems for conservationists seeking to protect the jaguar. One of the largest predators in Latin America, the jaguar is essential to maintaining equilibrium in rainforest ecosystems. Its role in limiting rodent populations in the forest is critical, controlling species that consume invertebrates and young plants on which the rainforest depends for regeneration. Industrial expansion in the few remaining patches of intact forest not only reduces the big felid's habitat, but also increases conservationists' fears of negative human-wildlife interactions, poaching and trafficking. Jaguar parts are used in Chinese Traditional Medicine and for exotic jewellery.

Source: The Guardian (2019) theguardian. com/environment/2019/nov/11/ecuadorsvanishing-jaguars-the-big-cat-vital-torainforest-survival

Invasive grasses may worsen wildfires The fires in California in October 2019, which led to mass evacuations and seemingly otherworldly scenes, may have emerged from a surprising source. Invasive grasses can make wildfires more frequent, not just in California but across the entire USA. A team of researchers looked at grasses such as cane grass, which is native to Myanmar but is damaging ecosystems in Florida, and buffelgrass, which originates from outside North America and is responsible for igniting fires in the south-western USA. The invasive species add to fire risk because they act like kindling in regions that once had far fewer grasses. In the absence of rainfall, the long, thin blades dry out quickly. This creates problems in places such as California where most rain falls in the autumn and winter, leaving the grasses to dry out in summer. Managing existing grass invasions and preventing future introductions is key to remediate the consequences of invasive species and fire.

Sources: Proceedings of the National Academy of Sciences of the United States of America (2019) doi.org/10.1073/pnas.1908253116 \& New York Times (2019) nytimes.com/2019/ 11/o4/climate/invasive-grasses-wildfires.html

\section{Critically Endangered vaquita porpoises spotted with babies}

In October 2019 marine scientists set out in the Gulf of California looking for vaquita porpoises Phocoena sinus, the world's smallest cetaceans and most threatened marine mammals, which they feared might already be extinct. They spotted a number of the animals, including mothers with calves, raising hopes that the Critically Endangered species can survive. The trip also brought discouraging news, as observers saw illegal fishing vessels in areas set aside for the vaquita. The species' populations have plunged as the animals become entangled in gillnets set by fishers. Scientists had assumed that vaquita mothers only calved every other year, which would allow their population to expand at $4 \%$ a year, given proper protection. In 2017 and 2018, however, they saw the same female with two separate calves, suggesting that they may breed annually, potentially doubling the estimated rate of growth. The key to vaquita recovery is clearing the waters of hazardous fishing gear.

Source: The San Diego Union Tribune

(2019) sandiegouniontribune.com/news/ environment/story/2019-11-22/scientistsspot-critically-endangered-vaquitaporpoises-with-babies

\section{Mysterious disease affecting American beech trees}

The American beech Fagus grandifolia is one of eastern North America's most important tree species, but in 2012 scientists identified a disease spreading rapidly from the Great Lakes to New England. Beeches in the USA were already struggling with a bark-infesting fungus when trees began exhibiting signs such as shrivelling leaves bearing black stripes. By 2018, foresters had documented beeches with similar symptoms across several states. Plant pathologists disagree over whether the disease is caused by infestations of a subspecies of the nematode worm Litylenchus crenatae, native to Asia and found in stricken trees, or whether the origin lies in pathogens such as bacteria or fungi carried by the worm, which may act as a vector. Beech trees are already struggling with the effects of devastating introduced threats such as the emerald ash borer beetle. The US Department of Agriculture's Animal and Plant Health Inspection Service is helping to study the problem, but is waiting to act until more is understood about the cause and spread of the disease.

Source: Science Magazine (2019) science mag.org/news/2019/11/mysterious-diseasestriking-american-beech-trees 


\section{ASIA \& OCEANIA}

\section{Cheetah researchers accused of spying sentenced in Iran}

Six conservationists from the Tehran-based NGO Persian Wildlife Heritage Foundation have been sentenced to 6-10 years imprisonment after an Iranian court returned a guilty verdict in November 2019. Nine members of the foundation had been arrested by the Islamic Revolutionary Guard Corps in early 2018 on charges of spying for foreign countries, based on their use of camera traps to study the Critically Endangered Asiatic cheetah Acinonyx jubatus venaticus. The Foundation's Managing Director, Kavous Seyed-Emami, died in custody in uncertain circumstances, and two of those arrested had yet to be sentenced at the time of writing. Despite continued international condemnation from the scientific community and human rights groups, Iran continues its crackdown against environmentalists. Critics point to the failure of the authorities to produce any evidence to support the spying allegations.

Source: National Geographic (2019)

nationalgeographic.co.uk/environment-andconservation $/ 2019 / 11 /$ cheetah-researchersaccused-spying-sentenced-iran

\section{Migrating Russian eagles run up huge data roaming charges}

Russian scientists tracking migrating eagles ran out of money after some of the birds flew to Iran and Pakistan and their short message service (SMS) transmitters drew huge data roaming charges. After learning of the team's dilemma, Russian mobile phone operator Megafon offered to cancel the debt and put the project on a special, cheaper tariff. The team had started crowdfunding on social media to pay off the bills. The birds had left from southern Russia and Kazakhstan, with SMS messages delivering the birds' coordinates as they migrated. The research team then used satellite photos to see if the birds had reached safe locations. Power lines are a particular threat for the steppe eagles, which are Endangered in Russia and Central Asia. The researchers are currently tracking 13 eagles. The birds breed in Siberia and Kazakhstan, but fly to South Asia for the winter. Megafon's offer to bail out the team, reported by RIA Novosti news, means they can continue monitoring the eagles' routes, collecting vital data to help ensure their survival. Source: BBC (2019) bbc.co.uk/news/worldeurope-50180781

\section{Socotra at a crossroads of} development and conservation

The four islands of the Socotra archipelago, located in the Arabian Sea off the coast of Somalia and Yemen, have been isolated from the mainland for millions of years, allowing the local wildlife to evolve in unique ways. Until recently, this assemblage of flora and fauna had remained relatively well preserved thanks to its isolation and the strong traditional relationship between the local people and their environment. However, the safe haven that Socotra once provided is now under threat from a series of new pressures that could jeopardize the archipelago's outstanding biodiversity. These include a rise in uncontrolled developments, increased use of insecticides, unsustainable use of natural resources and inadequate biosecurity regulations, which risk the introduction of invasive species. Such developments could disrupt Socotra's unique ecosystems, and threaten its UNESCO World Heritage Site status. In light of these emerging threats, national and international organizations must unite to help the Socotran decision-makers and community make conservation a top priority.

Source: BirdLife (2019) birdlife.org/middleeast/news/magical-socotra-stands-crossroadsconflict-and-conservation

\section{Conservation efforts save the golden Mahseer in India}

The golden mahseer Tor putitora has been saved from extinction through a conservation plan launched to improve its status in reservoirs and rivers of the Indian state Himachal Pradesh. India's nearly extinct fish, known locally as 'tiger of the water', which suffered severe population declines in recent years and is categorized as Endangered on the IUCN Red List, is threatened by pollution, habitat loss and over-fishing. The species is, however, still thriving in Himachal Pradesh's Mandi district through artificial breeding in captivity. The state is setting up another mahseer hatchery-cumcarp breeding in the Shimla district. Of the 41,450 eggs produced in 2019, up to 12,000 were expected to hatch. Nearly 70,000 eggs of the golden mahseer had been produced in the state since 2016. The mahseer is found in $500 \mathrm{~km}$ of the total $3,000 \mathrm{~km}$ of rivers in Himachal and attracts anglers from across the world. It is migratory and travels long distances upstream for breeding during the monsoon season.

Source: The Weather Channel (2019) weather.com/en-IN/india/news/news/ 2019-12-09-conservation-efforts-savegolden-mahseer-extinction
Four Sumatran tiger foetuses found in Indonesia

In December 2019, Indonesian authorities found four foetuses of the protected Sumatran tiger Panthera tigris sumatrae, and a hide of the same species, in two police raids carried out against suspected animal poachers and traffickers. Five people were arrested and three of them were charged with trafficking of protected animals. Sumatran tigers are found exclusively on the island of Sumatra and are categorized as Critically Endangered on the IUCN Red List, with only 400-600 individuals left in the wild. The police are investigating possible connections of the accused with prospective buyers, who generally seek body parts of tigers to make amulets for decorative use or to use in traditional medicine. If convicted, the suspects face up to 5 years in prison and fines of up to IDR 100 million (USD 7,100).

Source: The Pioneer (2019) dailypioneer. com/2019/world/4-sumatran-tiger-foetusesfound-in-jar-in-indonesia.html

\section{Hoiho first penguin to be New Zealand's Bird of the Year}

The yellow-eyed penguin Megadyptes antipodes, locally known the hoiho, has won New Zealand's coveted Bird of the Year competition in November 2019. Both former Dunedin mayor Dave Cull and incumbent Aaron Hawkins had campaigned for the species, which won the single transferable vote election after 43,460 votes were cast, beating its closest competitor, the kakapo. It was the first win for a seabird in the competition's 14-year history. In 2018 only 225 hoiho nests had been counted, and just 162 in 2019. The species faces numerous threats including warming oceans and changes in food availability, damaged feeding grounds as a result of bottom trawling, entanglement in fishing nets, and human disturbance. The win helps shine a spotlight on the hoiho, and it is hoped that the extra publicity will attract funding to save the bird.

Source: NZ Herald (2019) nzherald.co.nz/nz/ news/article.cfm?c_id=1\&objectid $=12284364$

All internet addresses were up to date at the time of writing. The Briefly section in this issue was written and compiled by Emma Muench, Julia Hochbach and Martin Fisher, with additional contributions from Rob Hyman and Annkathrin Sharp. Contributions from authoritative published sources (including websites) are always welcome. Please send contributions by e-mail to oryx@fauna-flora.org. 